\title{
Mediator role of difficulty in emotion regulation in relation between attachment to parents and social anxiety disorder symptoms in adolescent females
}

\author{
Yekta Deh Bozorgi ${ }^{1}$, Azam Davoodi ${ }^{2}$ \\ 1-Master of Psychology, Department of Psychology, Shiraz Branch, Islamic Azad University, Shiraz, Iran. \\ 2- Assistant Professor, Department of Psychology, Shiraz Branch, Islamic Azad University, Shiraz, Iran \\ (Corresponding Author). $\quad$ E-mail: davoodi.azam@yahoo.com
}

Received: 05/12/2019

Accepted: 09/02/2020

\begin{abstract}
Introduction: Attachment styles are those intrinsic sources in which can balance stress levels and disability in unpalatable situations and make the negative effects of tension less.

Aim: The purpose of this research is the mediator role of difficulty in emotion regulation in relationship between parental attachment and social anxiety disorder symptoms in adolescent females.

Method: This study is a correlation-descriptive research method and the statistical population of this study has been chosen among first grade of junior high school students in districts 1 and 2 of Shiraz in the school year of 2017-2018. In this research, a total of 175 students have been selected by multistage cluster sampling. Attachment, anxiety and emotion regulation difficulty were used for data collection. Data were analyzed using Pearson correlation test and path analysis test.

Results: Difficulty in emotion regulation is playing a mediator role in relation between parental attachment and social anxiety and there is a meaningful relationship between parental attachment and difficulty in emotion regulation of adolescent females $(\mathrm{P}<0.05)$.

Conclusion: As a result, it can be said that attachment to parents acts as an underlying mechanism in improving social anxiety function and the difficulty variable in emotion regulation causes symptoms of social anxiety disorder in adolescent females.
\end{abstract}

Keywords: Emotion regulation, Attachment, Parental attachment, Social anxiety

\footnotetext{
How to cite this article : Deh Bozorgi Y, Davoodi A. Mediator role of difficulty in emotion regulation in relation between attachment to parents and social anxiety disorder symptoms in adolescent females. Shenakht Journal of Psychology and Psychiatry. 2020; 7 (1): $43-56$.URL: http://shenakht.muk.ac.ir/article-1-612-fa.pdf
}

Copyright ( $\odot 2018$ the Author (s). Published by Kurdistan University of Medical Sciences. This is an open access article distributed under the terms of the Creative Commons Attribution-Non Commercial License 4.0 (CCBY-NC), where it is permissible to download, share, remix, transform, and buildup the work provided it is properly cited. The work cannot be used commercially without permission from the journal. 


\title{
نقش واسطهاى دشوارى در تنظيم هيجان در رابطه بين دلبستّى به والدين و علائم اختلال اضطراب اجتماعى در نوجوانان دختر
}

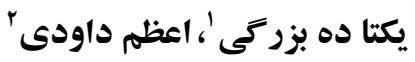 \\ ا.دانشجوى كارشناسى ارشد روانشناسى، گُروه روانشناسى، واحد شيراز، دانشخاه آزاد اسلامى، شيراز، ايران.
}

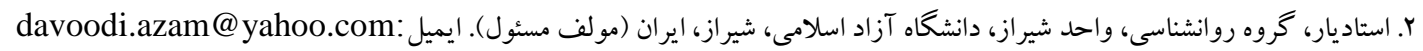

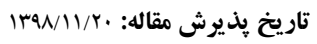

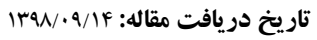

جكيده

مقدمه: سبككهاى دلبستخى از منابع درون فردى هستند كه مىتواند سبب تعديل سطوح تنش و ناتوانى در شرايط ناگوار شده و اثرات منفى تنش را كمرنغك تر جلوه دهند.

هدف: هدف اين تحقيق نقش واسطهاى دشوارى در تنظيم هيجان در رابطه بين دلبستگى به والدين و علائم اختلال اضطراب اجتماعى در نوجو انان دختر است.

روش: مطالعه حاضر از نوع توصيفى - همبستخى بوده و جامعه آمارى اين مطالعه شامل دانش آموزان مقطع متوسطه اول ناحيه يكك و دو

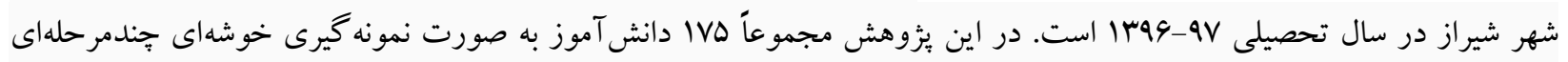
انتخاب شدند. بهمنظور گردآورى اطلاعات از دلبستخى، اضطراب و دشوارى تنظيم هيجان استفاده شد. دادهها با استفاده آزمون همبستخى بيرسون و آزمون تحليل مسير مورد تجزيه و تحليل قرار گرفتند.

يافته ها: نتايج نشان داد كه دشوارى در تنظيم هيجان در رابطه بين دلبستگى به والدين و اضطراب اجتماعى نقش واسطهاى ايفا مى كند

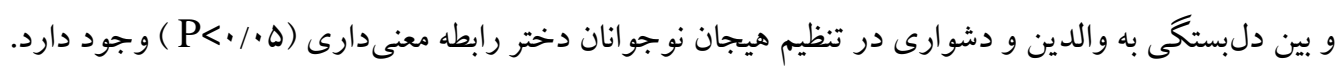

نتيجه كيرى: در نتيجه مى توان گفت دلبستگى به والدين به عنوان يكك مكانيسم زير بنايى در بهبود عملكرد اضطراب اجتماعى عمل

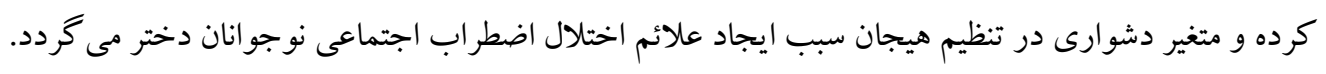
كليد وازهها: تنظيم هيجان، دلبستخى، دلبستخى به والدين، اضطراب اجتماعى 
تلاش فرد براى نكهدارى، بازدارى و افزايش تجارب و حالات هيجانى تعريف مى شود (بريدجز، دنم و كانيبان،

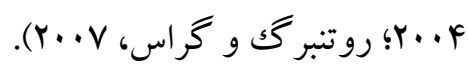

تحقيقات انجام شده نشان مىدهد كه تنظيم هيجانى مؤثر با سلامت روان و تنظيم هيجان ناكار آمد با دامنهاى از

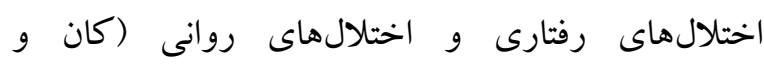

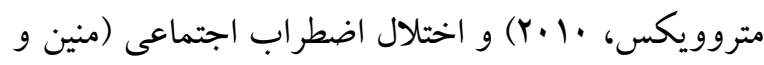

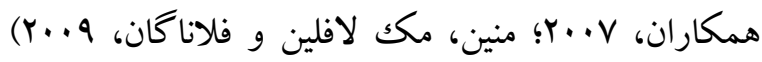
مرتبط است. طبق تحقيقات گزارش شده مشكلات تنظيم هيجان در اختلال اضطراب اجتماعى هم در سطح درون فردى و هم در سطح ميان فردى گزارش شده است

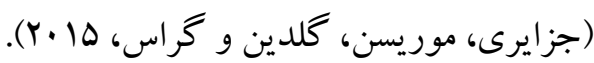
بخش عمدهاى از تنظيم هيجان ريشه در دلبستكى افراد

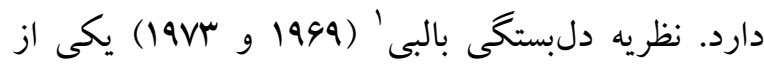
مفيدترين جِارجوب هاى مفهومى معاصر در درك تنظيم هيجان است. بالبى دلبستخى را در ويزگ گیى نوع انسان

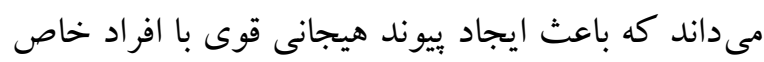
مىشود. تفاوتهاى فردى افرادى را در كاركردهاى سيستم دلبستكى كه نتيجه تجربيات اجتماعى با مراقبان در دوران نوزادى و كودكى است كه مبناى فر آيندهاى درونى و شناختى را توصيف مى كنند. دلبستكى ييوند عاطفى بين كودك و مادر است كه نقش تعيين كنندهاى

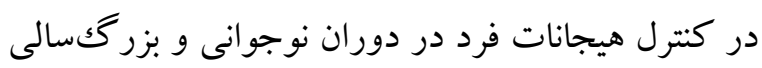

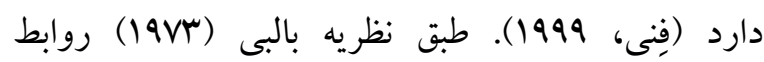
دلبستخى هميشه موجود و در سراسر خرخه زندكى فعال هستند؛ به اين معنا كه سوابق روابط عاطفى كودكى با مراقب خود بيامدهاى بلند مدتى را ايجاد كرده كه آثارش تا سنين بزرگكسالى به جشم مى خورد (كودوين،

\footnotetext{
1- Bowlby
}

\section{مقلدمه}

اختلالهاى اضطر ابى يكى از شايع ترين اختلالهاى دوران نوجوانى و جوانى هستند (توبرت و بينيكورات، 11) در واقع اختلال اضطرابى شامل اختلالاتى است كه ويز گى هاى ترس و نكرانى بيش از اندازه واقعى يا قريب الوقوع است، در حالى كه اضطراب بيش بينى تهلديد آتى است (انجمن روان بزشكى آمريكا، سا.ب). افراد مبتلا به اختلال هاى اضطرابى با اثرات منفى قابل ملاحظهاى بر عملكرد روانى اجتماعى خود مواجه هستند. براى مثال مطالعات اخير ارتباط منفى اختلالهاى اضطر ابى با كفايت اجتماعى، حرمت خود و بيشرفت تحصيلى نوجوانان را

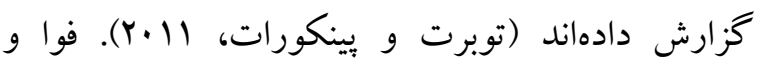
همكاران (1999) نشان دادند كه در مقايسه با افراد بهنجار، افراد مضطرب اجتماعى، ييامد منفى رويدادهاى اجتماعى را بالاتر بر آورد مى كنند. بيامد اختلال اضطراب اجتماعى در كودكان و نوجوانان با امتناع شديد از مدرسه ارتباط دارد (لاست و استراووس، ·199). اختلالهاى اضطرابى موجب مختل كردن عملكردهاى تحصيلى،

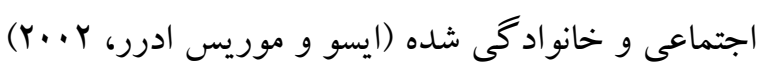
و اغلب اوقات يكك مسير مزمنى راطى مى كنند كه ممكن است تا بزرگكسالى ادامه يابد (رزا، هافسترا، وندرهند و وهالست، س...Y). همجينين اين اختلالات در دوران نوجوانى به عنوان يكى از قوى ترين بيشبينى كنندهاى

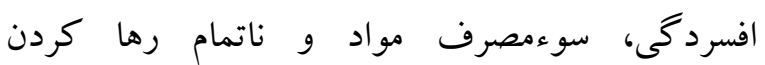
تحصيلات دانشگاهى در بزرگكسالى است (بوكنر،

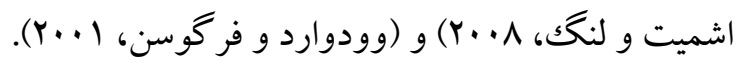
شواهد نشان مىدهد كه تنظيم هيجان ناكار آمد يكى از ويز كى هاى اصلى اختلال اضطر ابى است (منين، هولاوى،

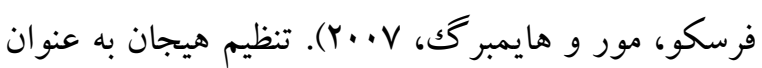


بنابراين مشكلات هيجانى تجربه شده توسط افراد مبتلا به اختلال اضطراب اجتماعى، ممكن است شامل عدم آكاهى از حالات هيجانى تجربه شده خود و همجِنين عدم توانايى براى تنظيم هيجانها باشد. شواهد جديد مربوط به اختلالهاى اضطرابى نشان مىدهد كه مشكل در تنظيم هيجان ممكن است عامل مهمى در اين اختلالها

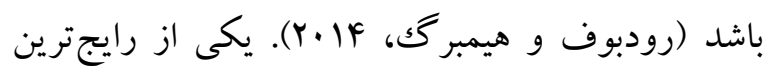
مشكلات روان بزشكى در دوران كودكى و نوجوانى اختلالات اضطر ابى است. تمايز بين اختلالات اضطر ابى با اضطرابهاى معمول اين دوران اهميت ويزهاى دارد (هالى، پِاسكار و ترهورست 1) اجتماعى سومين اختلال روانى و شايعترين اختلال اضطرابى است (منزس، كايتنهو، فونتنلى، ويخن، فيكوريا و وريسانى، (1) (Y). كسلر، بر كلوند، دملر، جين و ولترز

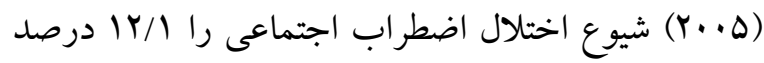
و شيوع l ساله آن را F/ه درصد گزارش كردند. افراد داراى اختلال اضطراب اجتماعى در مقايسه با افراد بدون اختلال روانى دستمزد بايينتر، احتمال اخذ بِيينترين مدركى دانشگاهى، نداشتن يكك شغل مديريتى، فنى يا حرفهاى، ناتوانى بيشتر در ارتباطات خانو ادكى، عاشقانه و اجتماعى و سابقه اقدام به خود كشى را در طول عمر دارند

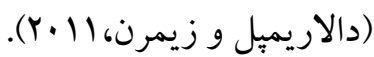
با توجه به تحقيقات ذكر شده اين بثوهش قصد دارد به

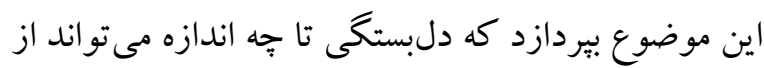
طريق تنظيم هيجانى علائم اختلال اضطراب اجتماعى را در نوجوانان بيشبينى كند. هدف اين مطالعه بررسى نقش واسطهاى دشوارى در تنظيم هيجان در رابطه بين

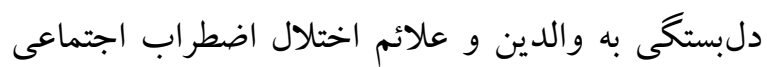
در نوجوانان دختر است.

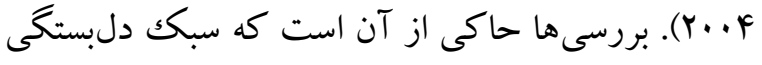
توان بيش بينى تنظيم هيجانى را دارد (استروبى، شات و

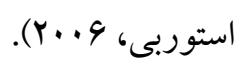
در اين زمينه مىتوان به نتايج يزوهشهايى مانند،

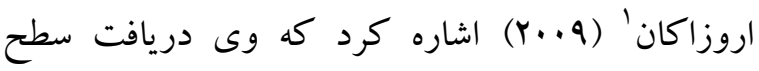
اضطراب اجتماعى افرادى كه دلبستخى ايمن داشتهاند، كمتر از افرادى است كه دلبستگى نايمن را تجربه

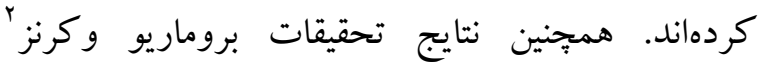
و (Y...9)

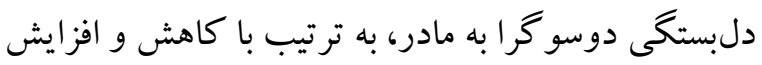
اضطراب اجتماعى رابطه معنادارى دارد و رابطه افراد داراى دلبستخى ايمن به مادر با همسالان از كيفيت بالاترى برخوردار است و شايستخى هاى اجتماعى بيشترى ليه دارد. افرادى كه داراى همبستگى ايمن بوده، اضطراب كمترى را نسبت به كروه نايمن نشان مىدهند و نيز سبك هاى دلبستخى اجتنابى و دوسو گرا به طور معنا

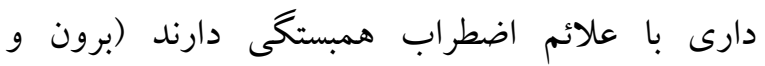

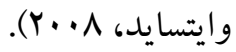
تحقيقات نشان داده است كه دلبستكى ناايمن راهبردهايى در تنظيم هيجان را راه اندازى كرده كه اين امر موجب بريشانى و آسيب يذيرى در واقع هيجانات روانى مىشود؛ به عبارتى توليد هيجانات وابسته به تغييرات ادراكك شده در محيط است؛ اين تغييرات خودكار و اغلب نا هوشيار در ارتباط با نياز اهداف، آرزوها، نگگرانىهاى فردى بوده و به عبارتى ديخر نوع

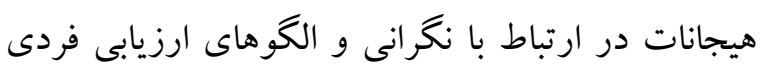

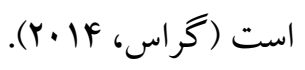

\footnotetext{
1- Erozkan

2- Brumariu
} 
(94 تا •9 درصد) و و ونج به معناى تقريباً هميشه (19 تا

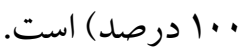

نتايج حاكى از اين است كه اين مقياس از همسانى درونى

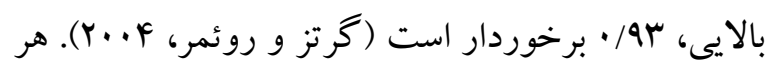
شش زير مقياس، آلفاى كرونباخ بالاى •^/·· دارند. بر

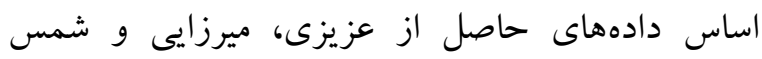

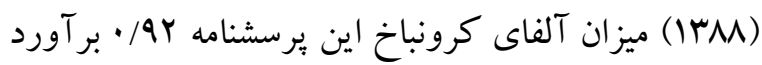
شده است. يرسشنامه دلبستكى والدين و همسالان (PPA)! اين يرسشنامه توسط آرمسدن و گرينبر گك (191V) جهت

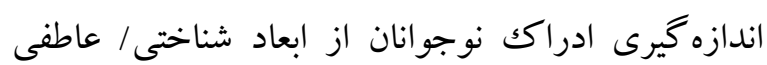
مثبت و منفى با والدين و دوستان صميمى طراحى شده كه

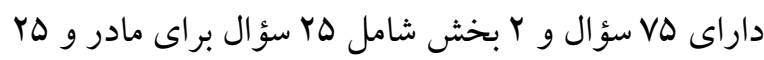
سؤال براى بدر است. اين برسشنامه از فرد در مورد

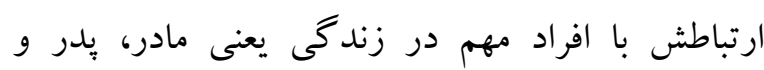

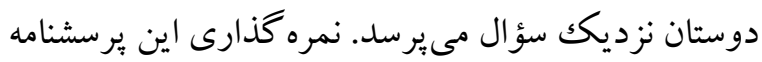
بر اساس طيف ها درجهاى ليكرت (هميشه:ه تا هيج كاه: (1)

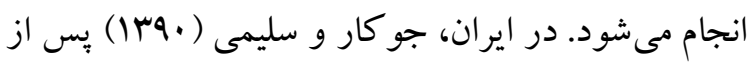
ترجمه و انطباق فرهنگى روايى و بايايى اين مقياس را

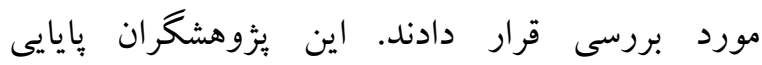

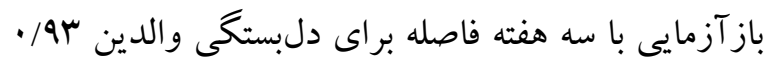
و براى همسالان 191• و و يايايى همسانى درونى براى دلبستخى مادر، پدر و همسالان به ترتيب AV/ • •، هץ/· به دست آوردند (جو كار و سليمى، •وسו)؛ در

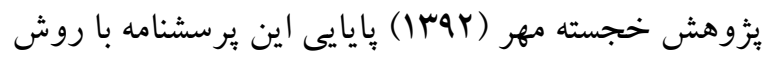
آلفاى كرونباخ و تنصيف محاسبه شد كه در دامنههاى

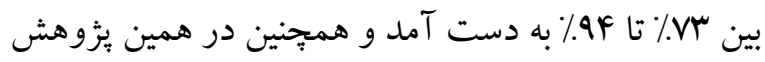
روايى يرسشنامه در روش آزمون مجدد در فاصله سه هفته

\footnotetext{
${ }^{2}$ - Inventory of Parent and Peer Attachment
}

يُزوهش حاضر از نوع توصيفى و مبتنى بر مدلهاى همبستكى بود. جامعهى بزُوهش شامل تمام دانش آموزان دختر متوسطه اول نواحى آموزش و يرورش شهرستان شيراز در سال تحصيلى IVD

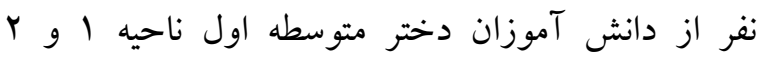
آموزشوبرورش شهرستان شيراز در رده سنى سا تا 19 سال بوده كه با استفاده از روش نمونه گيرى خوشهاى جند مرحلهاى انتخاب شدند، بدين صورت كه ابتدا از بين

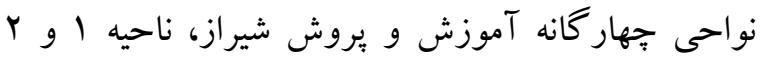

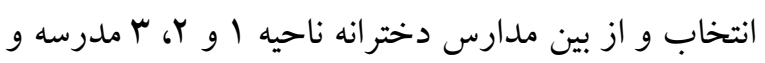
از هر مدرسه دو كلاس و سبس تمام دانش آموزان آن كلاس به عنوان نمونه انتخاب و مورد استناد قرار گرفتند.

ابزار ابزار جمع آورى اطلاعات برسشنامه بوده است كه در

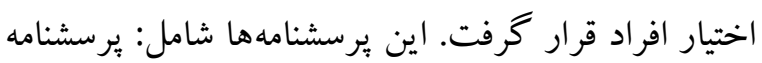
دشوارى در تنظيم هيجان كرتز و روئمر، برسشنامه دلبستخى والدين و همسالان و برسشنامه استاندارد مقياس اضطر اب اجتماعى نوجوانان لاجر كا است. مقياس دشوارى در تنظيم هيجان كرتز و روئمر (DERS)

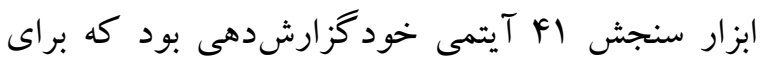
ارزيابى دشوارى در تنظيم هيجانى از لحاظ بالينى تدوين

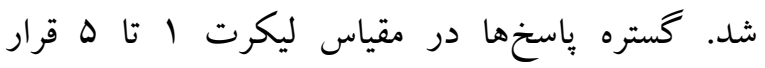

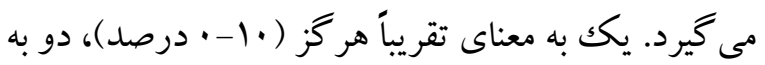

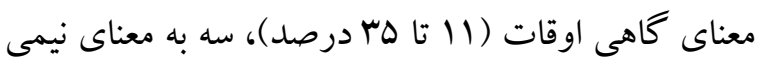
از مواقع (وس تا هو درصد)، جهار به معناى اكثر اوقات 
در يثزوهش قلى يور (سهبا) براى بررسى پايايى ابزار از ضريب آلفاى كرونباخ استفاده شده است. با استفاده از ضريب آلفاى كرونباخ بايايى مقياس اضطراب اجتماعى و زير مقياسهاى آن، ترس از ارزيابى منفى، اجتناب عمومى و اندوه جديد، اجتناب اجتماعى و اندوه عمومى با استفاده از ضريب آلفاى كرونباخ به ترتيب برابر با

$$
\text { . • • • • • • • • • • • • • }
$$

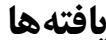
مؤلفههاى توصيفى مربوط به اضطراب اجتماعى، سبكهاى دلبستكى به والدين و دشوارى در تنظيم هيجان در جدول ا گزارش شده است.
بر روى يكك نمونه YV نفرى از آزمودنىهاى | |- ·Y ساله

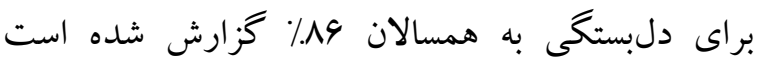

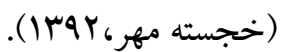

يرسشنامه استاندارد مقياس اضطراب اجتماعى نوجوانان

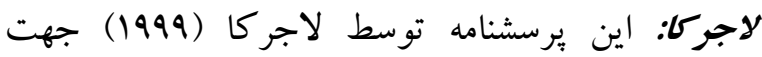
اندازه گيرى اضطراب اجتماعى نوجوانان طراحى شده كه داراى 1 \ سؤال و ب مؤلفه است: مؤلفه هاى برسشنامه از سه زير مقياس، ترس از ارزيابى منفى، اجتناب اجتماعى و اندوه در موقعيتهاى جديد، اجتناب اجتماعى و اندوه عمومى تشكيل شده است. نمره گذارى اين برسشنامه بر اساس طيف ه درجهاى ليكرت (كاملاً شبيه من: ه تا حدودى شبيه من: Fل، نظرى ندارم: كا، متفاوت از من: Y،

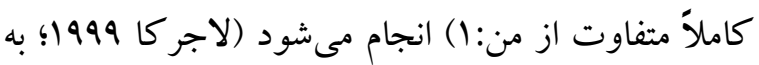

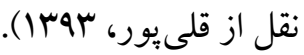

\begin{tabular}{|c|c|c|c|}
\hline انحر اف معيار & 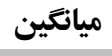 & ت تعداد & 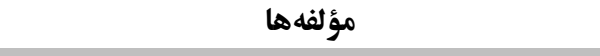 \\
\hline r/qr & $19 / 99$ & ivo & ترس از ارزيابى منفى \\
\hline$\Delta / v 9$ & $|F / Y|$ & ivo & اجتناب اجتماعى و اندوه در موقعيتهاى جديد \\
\hline $9 / \cdot 1$ & $I r / T V$ & IVD & اجتناب اجتماعى و اندوه عمومى \\
\hline $1 F / V^{F}$ & $F F / D F$ & IVD & اضطر اب اجتماعى (كل) \\
\hline$\Delta / \cdot r$ & IY/YF & IVD & عدم پذيرش پاسخهاى هيجانى \\
\hline $0 / \cdot 9$ & $\mid F / M$ & IVD & دشوارى در انجام رفتار هدفمند \\
\hline$\Delta / \wedge$. & $1 F / 99$ & IVD & دشوارى در كنترل تكانه \\
\hline $4 / 49$ & $18 / 49$ & ivo & فقدان آكاهى هيجانى \\
\hline V/YG & $19 / \cdot F$ & IVD & دسترسى محدود به راهبردهاى تنظيم هيجان \\
\hline$r / r q$ & $11 / \cdot r$ & IVD & عدم وضوح هيجانى \\
\hline$r I / r r$ & $\wedge q / 1 F$ & IVD & دشوارى در تنظيم هيجان (كل) \\
\hline $1 \cdot 19$ & $V \Delta / T r$ & IVD & دلبتكى به يدر \\
\hline Q/Dr & $V 9 / Y q$ & IVD & دلبستىى به مادر \\
\hline $19 / 1 F$ & $101 / 94$ & ivo & دلبتغى به والدين (كل) \\
\hline
\end{tabular}




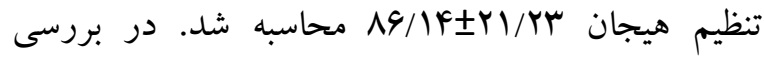
مؤلفه دلبستگى به والدين، ميانگين مؤلفه دلبستخى به يدر بيش از ميانكين مؤلفه دلبستخى به مادر بوده و

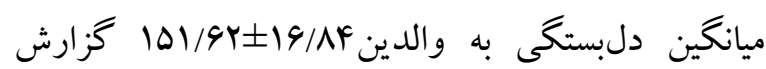
شده است. جدول r، شاخص هاى برازش مدل را نشان مىدهد.
در جدول شمارها، در بررسى مؤلفه اضطراب اجتماعى، ميانكين مؤلفه ترس از ارزيابى منفى از ساير مؤلفهها بيشتر FF/DF士IF/VF بوده و ميانخين اضطراب اجتماعى محاسبه شد. در بررسى مؤلفه دشوارى در تنظيم هيجان، ميانكين مؤلفه دسترسى محدود به راهبردهاى تنظيم هيجان از ساير مؤلفها بيشتر بوده و ميانكين دشوارى در

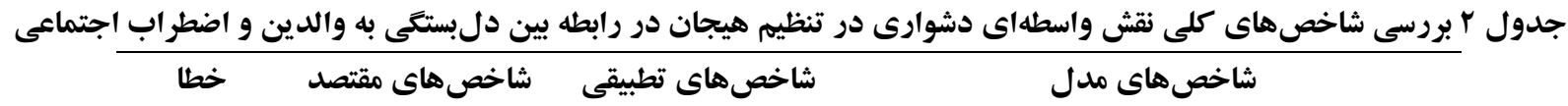

\begin{tabular}{|c|c|c|c|c|c|c|c|c|}
\hline RMSEA & PCFI & PNFI & TLI & CFI & CMIN/DF & سطح معنى & آزادى درجه & CMIN \\
\hline $.1 \cdot 11$ & .199 & $\cdot 194$ & $\cdot / 9$ & $\cdot / 91$ & r/FA &.$/ \cdot 1$ & r & $11 f / v a$ \\
\hline
\end{tabular}

تحت بررسى تمام اين شاخصها در محدوده نرمال قرار داشته و نشان از برازش مطلوب مدل دارد. همبِنين مقدار ريشه ميانگين باقى مانده نيز بايد كوجِكتر از هـ/ • باشد كه در مدل تحت بررسى برقرار است. در مجموع اين شاخص ها نشان مىدهند كه مدل ارائه شده مدل مطلوبى است و به خوبى با دادههاى تجربى مطابقت دارد. ضرايب همبستكى بيرسون بين سبككهاى دلبستكى، دشوارى تنظيم هيجان و نشانهاى اضطراب اجتماعى در جدول r نشان داده شده است.
با توجه به شاخصهاى برازش كه در جدول r مشاهده مىشود، مدل فرضى يزّوهش از برازش مطلوب برخوردار است. نسبت مورد نظر اين مفروضه برقرار است. همينطور ريشه خطاى ميانكين مجذورهاى تقريب جهت برازش مطلوب بايد كمتر از ه•/ • باشد كه در اين مدل تقريباً نزديك به صفر است. ميزان مؤلفهاى شاخص برازش، شاخص تعديل شده برازش، شاخص برازش هنجار شده و شاخص برازش تطبيقى نيز بايد بيشتر از 9 • • باشد كه در مدل

جدول r خلاصه هارامترهاى بر آورد شده نقش واسطهاى دشوارى در تنظيم هيجان در رابطه بين

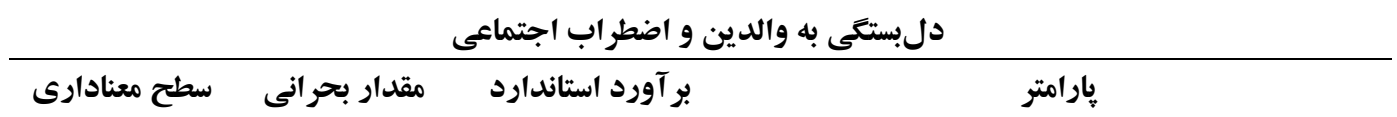

\begin{tabular}{|c|c|c|c|}
\hline$\cdot 1 \cdot r q$ & $-\cdot / 19$ & $-\cdot /$ YFD & دلبستخى به والدين ـ دشوارى در تنظيم هيجان (اثر مستقيم) \\
\hline$\cdot / \cdot r$ & $r / \mu r$ & $\cdot / r V$ & دشوارى در تنظيم هيجان ـ اضطر اب اجتماعى (اثر مستقيم) \\
\hline$\cdot / \cdot r \Delta$ & ------ & $-\cdot / \cdot 9$ & دلبستخى به والدين ـ اضطر اب اجتماعى (اثر غيرمستقيم) \\
\hline
\end{tabular}

وجود دارد. همجِنين نتايج تحليل جدول شماره م نشان با توجه به جدول شماره ب بين دشوارى تنظيم هيجان و داد كه دشوارى در تنظيم هيجان در رابطه بين دلبستخى نشانهاى اضطراب اجتماعى همبستكى مثبت معنادار 


$$
\begin{aligned}
& \text { به والدين، اضطراب اجتماعى نقش واسطهاى ايفا مى كند. معنىدارى r./ · معنىدار است. همجنين اثر غيرمستقيم }
\end{aligned}
$$

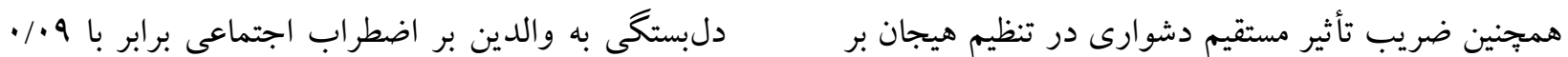

$$
\begin{aligned}
& \text { اضطراب اجتماعى ادراكشده VV/· است و در سطح است كه در سطح ץ./• معنىدار است. }
\end{aligned}
$$

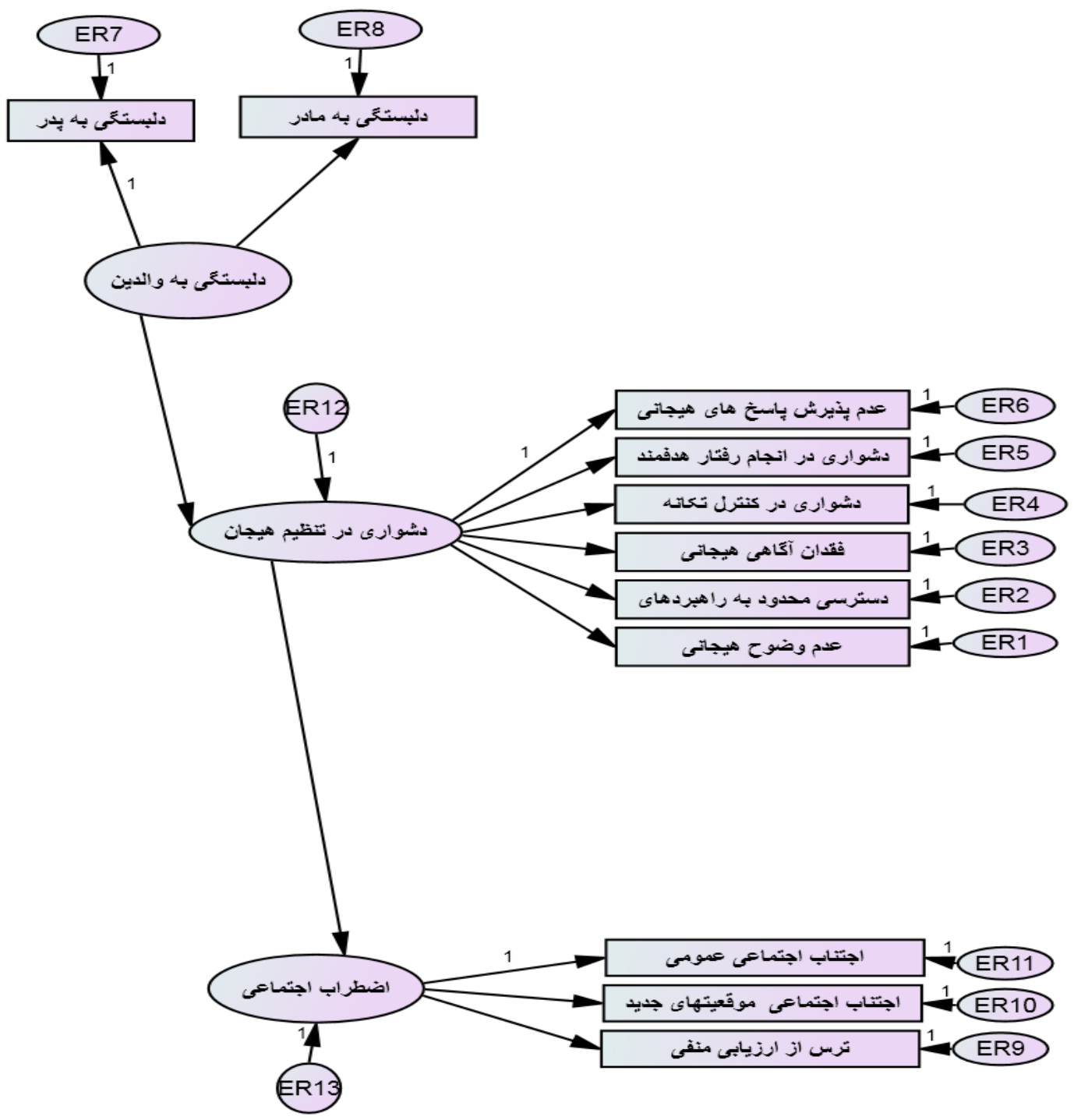

شكل ا مدل مفهومى نقش واسطهاى دشوارى در تنظيم هيجان در رابطه بين دلبستغى به والدين و اضطراب اجتماعى 


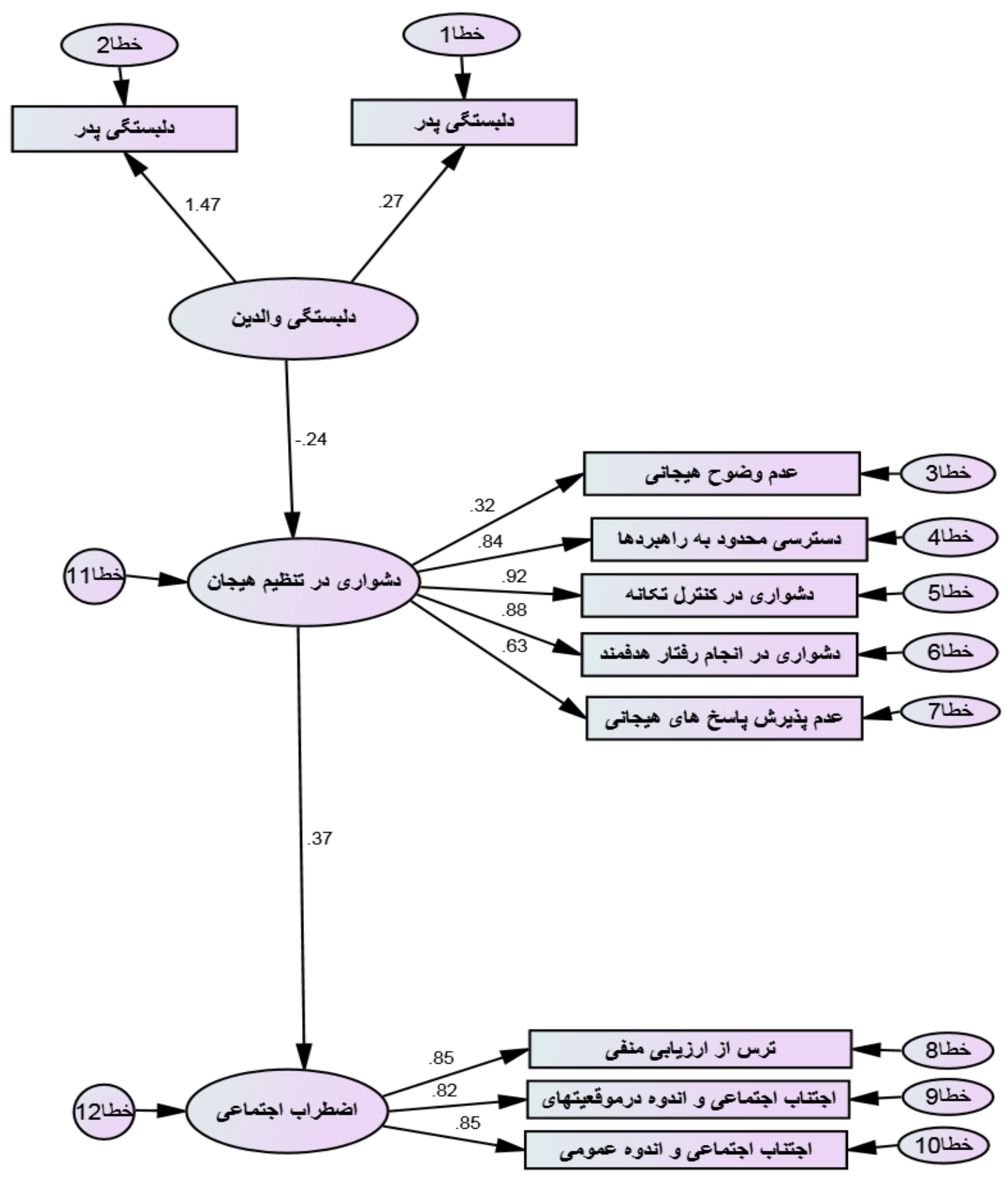

شكل r مدل اندازه Fيرى شده نقش واسطه اى دشوارى در تنظيم هيجان در رابطه بين دلبستعى به والدين و اضطر اب اجتماعى 
كردن، بازدارى و كاهش ابراز هيجان همراه است (دى

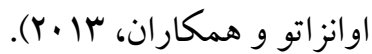
همان گونه كه نتايج يُزوهش نشان داد، بين دلبستخى به وله والدين و دشوارى در تنظيم هيجان نوجوانان دختر رابطه معنىدارى وجود دارد. اين يافته با يافتهاى تاشكه و بازانى (rMaq)، كلدوز خياط و رنجبر كهن (سوسا)،

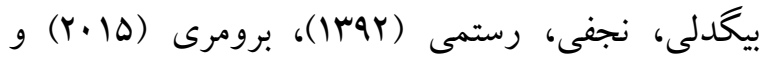
كويرو شيور و كولينز (1991) همسو است. در تبين اين

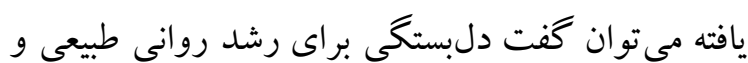
شكل گيرى شخصيت سالم و تنظيم هيجانى مطلوب ضرورى است. توانايى فرد در تنظيم هيجاناتش مستلزم

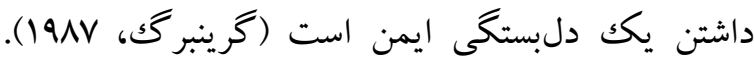
دلبستگى ييوند و رابطه بين فردى است و اين ارتباط يك ارتباط عاطفى است و مسلم است كه هيجانهاى مختلفى در اين ارتباط دركير خواهند بود و اين ارتباط نسبتاً بِيدار است؛ بنابراين با توجه به الكَوهاى بِايدار

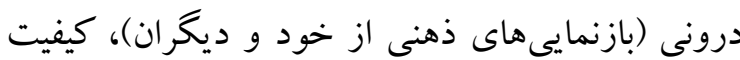
اين بيوند، حوزههاى وسيعى از روابط بين فردى و درون فردى را در زمان حال و آينده تحت تأثير قرار خواهد داد و تأثير مستقيم بر تنظيم هيجانات فرد دارد (ماير،

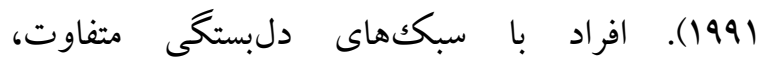

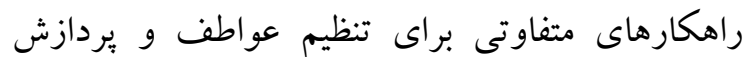

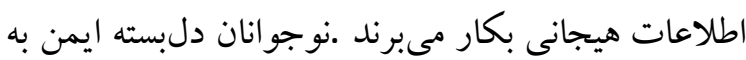
والدين و همسالان، در ارتباطهاى خود از شيوهاى كار آمد و مؤثر ارتباطى استفاده كرده و توانايى مديريت

$$
\text { ارتباط عاطفى و هيجانى خود راد ارند. }
$$
همان كونه كه نتايج يثوهش نشان داد بين دلبستخى به والدين با همه ابعاد اضطر اب اجتماعى رابطه منفى و معنى بـى بردي دارى وجود دارد. اين يافته با يافتهاى بيرامى و محبى
نتايج تحليل بئوهش نشان داد، دشوارى در تنظيم هيجان در رابطه بين دلبستكى به والدين، اضطراب اجتماعى نقش واسطهاى ايفا مى كند. اين يافته با يافتهاى تاشكه و

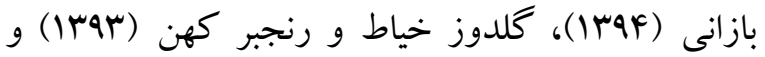
كويرو شيور و كولينز (1991)، همسو است. اين يافته بر اساس جند احتمال قابل تبيين است. غيرفعال سازى راهبردهاى دلبستخى (سبك اجتنابى) با تنظيم هيجانى تداخل بيدا مى كند و منجر به فرونشانى يا انكار هيجانها و متكى بودن به باورهاى بيش بر آورد شده برترى و كفايت مىشود. در مقابل، بيش فعالسازى راهبردهاى دلبستگى (سبك اضطرابى) شامل نشخوار افراطى هيجانهاى متعارض، دلمشغولى در خصوص بى ثباتى

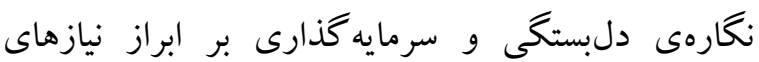

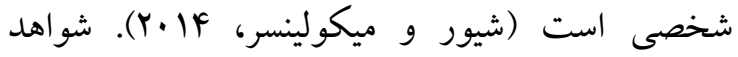
فزاينده، حاكى از آن است كه افراد با سبك دلبستگى نايمن در تنظيم هيجان مشكل دارند و اين مسئله آنها

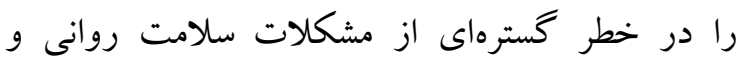
اختلالات شخصيت قرار مىدهد (لوى، ه · (Y). همجِنين برخى از راهبردهاى تنظيم هيجان با آسيب روانى همجيون اضطراب همراه است. يكى از اين راهبردها نشخوار بوده كه با بيامدهاى منفى براى خلق و عملكرد

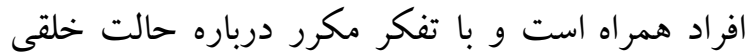
منفى و دلايل و وبيامدهاى آن مشخص مىشود. نشخوار گرى با فعال كردن شناختهاى منفى در حافظه مرتبط است و مىتواند منجر به گوشه گيرى از روابط بين فردى و در نتيجه مشكلات هيجانى از قبيل اضطراب

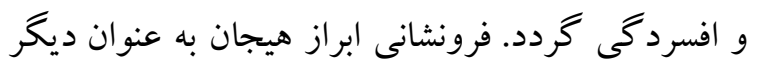
راهبرد سازش نايافته هيجان، با تلاش فرد براى ينهان 
مى كند. وقتى انسان به ديخران اعتماد داشته باشد و از

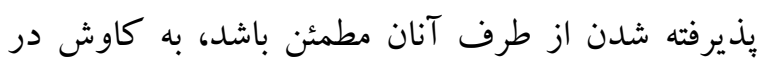
محيط اشتياق بيشترى نشان مىدهد، عواطف مثبترى مى يابد، از عزت نفس بالاترى بهرممند مىشود، در حل

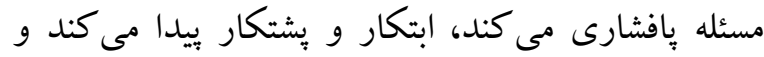
بهعبارت ديخر از ساز كارى اجتماعى و عاطفى بيشترى

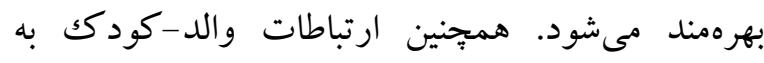
عنوان مدلى كه ارتباطات اجتماعى را شكل مىدهد در نظر گرفته مىشود و كود كانى كه بهطور ضعيف دلبسته

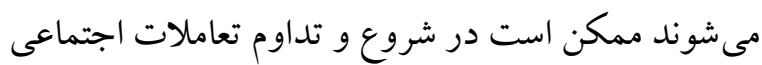

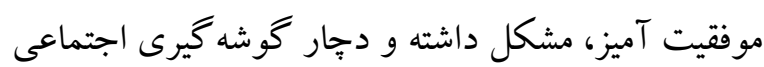
و دورى از همسالان شوند؛ بنابراين دلبستخى ضعيف

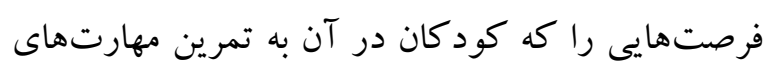
اجتماعى مؤثر مى يردازند، محدود كرده و طبيعى است

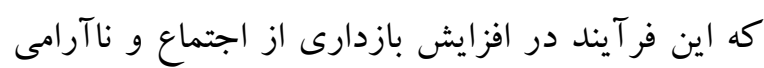
در موقعيتهاى اجتماعى نقش ايفا مى كند (برومارى و

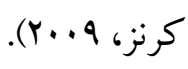

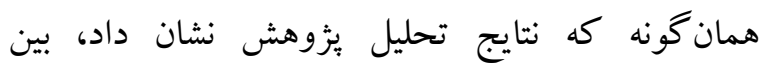
دشوارى در تنظيم هيجان و علائم اختلال اضطراب اجتماعى نوجوانان دختر رابطه معنادارى وجود دارد. اين

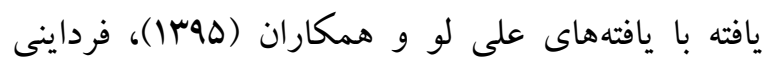

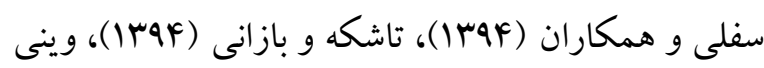

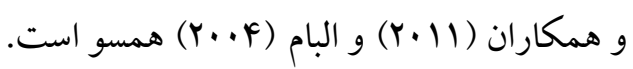

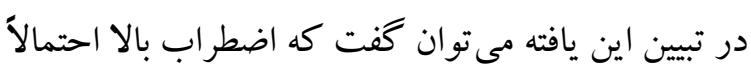
به استفاده از راهبردهاى تنظيم هيجانى مؤثر آسيب وارد كرده و بنابراين به طور منفى بر فر آيندهاى بين فردى و

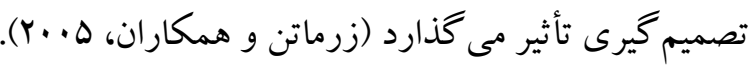
در موقعيتهاى بين فردى، افرادى كه سطوح بالاتر اضطراب را تجربه مى كنند، ممكن است بيشتر مستعد

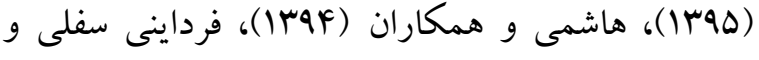

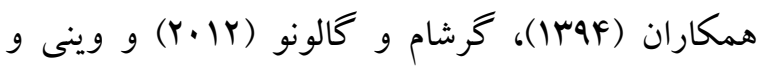

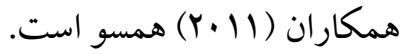
بالبى معتقد است كه يك شخص براى رشد سالم نياز به

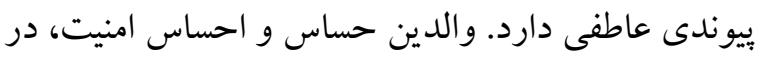
كودك بايهاى براى سلامت روانى وى مىباشند و رابطه

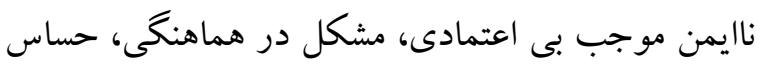
بودن و نارضايتى هيجانى در روابط عاشقانه مىشود. روابط دلبستخى نقش بسيار مهمى در احساس امنيت ما دارند. دلبستخى مفهومى است كه ريشه در كارهاى كردارشناسان دارد و داراى بار مفهومى روال تحليل خرانه

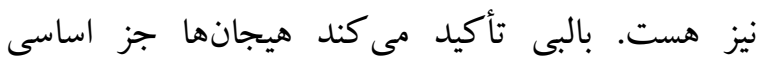

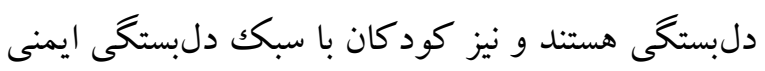
داراى تجارب سرشار از ايمنى و به دور از اضطراب

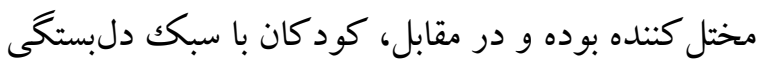
نا ايمن (اجتنابى - دوسو كرا) دنيا را محيطى نامن و و

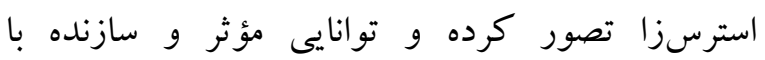
مشكلات و موقعيتهاى تنشزا راندارند. كودكان با مادر سبك دلبستخى ايمن خواهان تعامل، همكارى و رفتار جسبندگى به مراقب خود بوده و در إدن حضور او احساس راحتى مى كند. كودكان با سبك

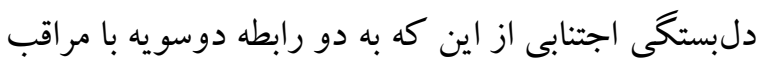

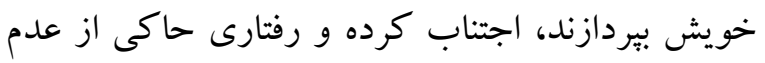
راحتى نشان را مىدهد كه از يك طرف خواهان كرايش به مراقب و تعامل به او بوده و از سوى ديخر خواستار

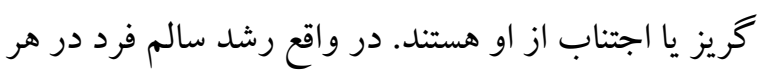
دوره، معلول عواملى است كه يكى از مهمترين آنها،

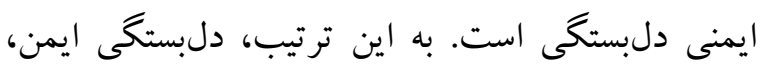

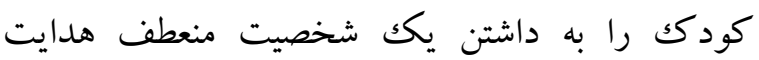


يثوهش كليه نوجوانان دختر شهر شيراز است و نتايج آن قابل تعميم به ساير افراد و گروهها نيست. يزوهش حاضر از نوع مقطعى بود، با توجه به اين مسئله كه در جنين يخزوششهايى امكان اظهار نظر دقيق درباره رابطه على بين متغيرهاى بثزوهش وجود ندارد، لازم است مطالعات طولى انجام يذيرد تا روابط بين متغيرها روشنتر شود.

\section{نتيجه كيرى}

نتايج تحليل يزوهش نشان داد دشوارى در تنظيم هيجان در رابطه بين دلبستگى به والدين، اضطراب اجتماعى لهي نقش واسطهاى ايفا مى كند. همجينين بين دلبستخى به به به والدين و دشوارى در تنظيم هيجان نوجو انان دختر ارتباط معنىدارى وجود دارد و بين دلبستخى به والدين با همه ابعاد اضطراب اجتماعى رابطه منفى و معنىدارى وجود دارد. همجينين نتايج تحليل يُزوهش نشان داد بين دشوارى در تنظيم هيجان و علائم اختلال اضطراب اجتماعى نوجوانان دختر رابطه معنادارى وجود دارد.

\section{سياسگز ارى}

از تمامى افرادى كه در اين مطالعه شركت كردند و در انجام اين يزوهش ما را يارى نمودند كمال تشكر راني

$$
\text { داريم. }
$$

\section{References}

Armesden GC, \& Green berg MT. (1987). The Inventory of parent and peer attachment. Relationships to well- being in adolescence. Journal of Youth and Adolescence, 16(5), 427-454.4.

Azizi A, Mirzaei \& Shams J. (2010). Comelation between distress tolerance and emotion regulations with students smoking
تجربه دشوارى در رفتار هدفمند باشند. اين يافتها، همسان با شواهد نظرى و تجربى است كه نشاندهنده نقش تنظيم هيجان در آشفتخىهاى روان شناختى و آسيبهاى روانى است (منين و همكاران، هـ+ץ)؛ بنابراين، به نظر مىرسد تنظيم هيجان مىتواند جارجوبى سودمند براى مفهوم سازى اختلالهاى اضطرابى باشد

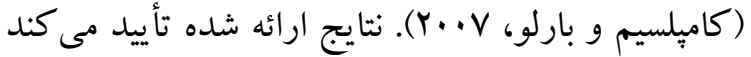
تفاوتهاى فردى در استفاده از راهبردهاى تنظيم هيجانى منفى ممكن است نقش مهمى در شروع و تداوم اضطراب

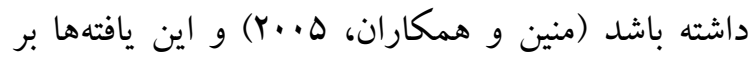
اهميت به كارگيرى انعطافيذير راهبردهاى تنظيم هيجان، به منظور انطباق بهتر تأكيد دارند. افراد داراى اختلال اضطراب اجتماعى از موقعيتهاى اجتماعى اجتناب مى كنند؛ زيرا فقدان كنترل درونى بر روى بِاسخ

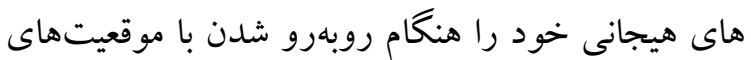
اضطراب اجتماعى ويشبينى مى كنند. به نظر مىرسد قابليت تشخيص و بيان تجارب هيجانى، جنبه هايى از تنظيم هيجان بوده كه در افراد دجار اضطراب اجتماعى مختل شده است. فرآيندهاى شناختى تنظيم هيجان مىتو انند به افراد كمكك كرده تا بتوانند مديريت يا تنظيم هيجانها يا عواطف را بر عهده بخيرند تا از اين طريق بر بر بر برد مهار هيجانها بعد از وقايع اضطرابآور توانا باشند

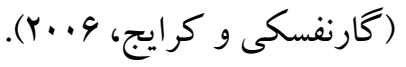

بديهى است كه اين تحقيق همجِون ساير بثزوهش ها داراى محدوديتهايى است؛ در اين ثئوهش، براى جمع آورى اطلاعات تنها از يرسشنامه استفاده شد كه خالى از سو گيرى نيست و اكر امكان استفاده از ابزارهاى سنجشى

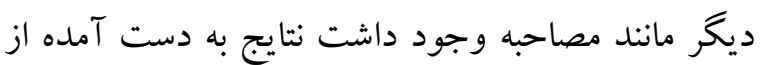
يُزوهش دقيقتر به دست مى آمد. جامعه آمارى اين 
dependence. Journal of Hakim Health sys res, 13(1):11-18. \{InPersian\}

Bayrami M \& Mohebbi M. (2016). Relationship between attachment to parents and perception of conflict between parents with social anxiety disorder in female students: The mediating role of emotion-oriented coping strategy. Joumal of Clinical Psychology, vol.8, 1(29). \{In Persian\}

Bigdeli I, Najafy M, Rostami M. (2013). The relation of attachment styles, emotion regulation and resilience to well-being among students of medical sciences. Iranian Joumal of Medical Education, 13(9): 721-729. \{In Persian $\}$

Brown AM \& Whiteside SP. (2008). Relations among perceived parental rearing behaviors, attachment style, and worry in anxious children. Journal of Anxiety Disorder. 2008; 22: 263-72.

Brumariu LE \& Kerns KA. (2009). Mother-child attachment and social anxiety symptoms in middle childhood. Joumal of Applied Development Psychology, 2, P: 393-402.

Buckner JD, Schmidt NB, Lang AR, Small JW, Schlauch RC \& Lewinsohn PM. (2008). Specify of social anxiety disorder as a risk Factor for alcohol and cannabis dependence. Journal Psychiatric Research Elsevier. 42: 230-9.

Campbell-Sills L \& Barlow DH. (2007). Incorporating emotion regulation into conceptualizations and treatments of anxiety and mood disorders. $\mathbb{N}$ : Gross JJ, Editor. Handbook of Emotion Regulation. $2^{\text {nd }}$ Ed. New York: Guildford Press, 542-59.

Cooper M, Shaver R \& Collins L. (1998). Attachment styles, emotion regulation, and adjustment in adolescence. Joumal of Personality and Social Psychology, Vol 74(5): 1380-1397.

D'Avanzato C, Joormann J, Siemer M \& Gotlib IH. (2013). Emotion Regulation in Depression and Anxiety: Examining Diagnostic Specificity and Stability of Strategy Use. Cognitive Therapy Research, 37, 968-980.

Essau CA, Muris P, Ederer EM. (2002). Reliability \& validity of the Spence children's anxiety scale and the screen for child anxiety related emotional disorders in German children. Joumal of Therapy Behavior Exercise Psychology, 33: 1-18.

Fardaeni-Sofla H, Karsazi H, Emami-Ezat A, \& Bakhshipour-Roodsari A. (2015). The structural relationship of anxiety sensitivity, worry and difficulty in regulating emotions with generalized anxiety disorder, social anxiety disorder and panic disorder. Joumal of Thought \& Behavior in Clinical Psychology, Vol.9, No: 63.77-92. \{In Persian $\}$

Gamefski N, Kraaij V \& Van Etten M. (2005). Specificity of relations between adolescents' cognitive emotion regulation strategies and internalizing and externalizing psychopathology. Joumal of Adoles, 28, 619631.

Goldoz-Khayat N, Ranjbar-Kohan Z. (2014). Relationships between attachment styles and cognitive-emotional regulation in children and adolescents. Amin Perspective Quarterly in Applied Psychology, year1, NO.1 (piano2). \{InPersian $\}$

Goodwin I. (2003). The relevance of attachment theory to the philosophy, organization, and practice of adult mental health care. Clinical Psychology Review. 23(1): 35-56.

Gratz KL \& Roomer L. (2004). Multidimensional assessment of emotion regulation and dysregulation: development, factor structure, and initial validation of the difficulties in emotion regulation scale. Journal of Psychology and Behavioral Assessment, 26, 41-54.

Greenberg MT. (1987). The inventory of parent and peer attachment: Individual differences and their relationship to psychological well-being in adolescence. Joumal of Youth Adolescent, 16: 427-54.

Hashemi T, Ahmad-beigi N, Parvaz S \& Karimi R. (2015). The role of attachment style in being social with regard to mediating effects of selfsteam. Joumal of Psychological Achievements of Education Sciences and Psychology, Shahid Chamran University of Ahvaz, VOL 4, issue 22(1), PP47-66. \{In Persian $\}$ 
Jazaieri H, Morrison AS, Goldin PR \& Gross JJ. (2015). The Role of Emotion and Emotion Regulation in Social Anxiety Disorder. CurrentPsychiatry Report. 2015; 17:1-9.

Khojasteh-Mehr R, Mombeini J \& Aslani KH. (2013). A comparison of attitude toward mamiage, attitude toward divorce and peer attachment of male high school students in divorced and intact families. Joumal of School Psychology, vol.2 no3, 182-190. \{InPersian\}

Kun B. Demetrovics Z (2010). Emotional intelligence and addictions: A systematic review. Substance Use Misuse. 45(7-8): 1131-60.

Last CG \& Stanuss CC. (1990). School refusal in anxiety disordered children \& adolescents. The Behavior Therapy, 22, 133-1360.

Mennin DS, Heimberg RG, Turk CL \& Fresco DM. (2005). Preliminary evidence for an emotion dysregulation model of generalized anxiety disorder. Behave Research Therapy, 43(10):1281-310.

Mennin DS, Holaway RM, Fresco DM, Moore M \& Heimberg RG. (2007). Delineating components of emotion and its deregulation in anxiety and mood psychopathology. Behavior Therapy Joumal, 38:284-302.

Mennin DS, McLaughlin KA \& Flanagan TJ. (2009). Emotion regulation deficits in generalized anxiety disorder, social anxiety disorder, and their co-occurrence. Joumal of Anxiety Disorders, 23(7): 866-871.

Rotenberg J \& Gross JJ. (2007). Emotion \& emotion regulation: A map for psychotherapy researchers. Clinical Psychology- Science and Practice, 14(4): 323-8.

Roza SJ, Hofstra MB, VanDer-Hende J \& Verhulst FC. (2003). Stable prediction of mood and anxiety disorders based on behavioral and emotional problems in childhood: A year follow-up during childhood, adolescence, and young adulthood. The American Joumal of Psychiatry, 160: 2116-21.

Shaver PR \& Mikulincer M. (2014). Adult attachment and emotion regulation. IN: Gross JJ Editor, Handbook of Emotion Regulation. $2^{\text {nd }} \mathrm{Ed}$, New York: Guilford Press, 237-250.
Stroebe M, Schut H \& Stroebe W. (2006). Who benefits from disclosure? Exploration of attachment style differences in the effects of expressing emotions. Clinical Psychology Review, 26(1):66-85.

Tashkeh M \& Bazani M. (2015). Prediction of social anxiety by cognitive emotional regulation and emotional schema in female and male students. Joumal of Medical Sciences. 16 (50):72-83. \{In Persian\}

Winnie E, Richard G, Treuora H \& Frankin R. (2011). Emotion Data Base: Joumal of Psychology Articles, 1(4).365-380.

Woodward LJ \& Fergusson DM. (2001). Life course outcomes of young people with anxiety disorders in adolescence. Journal of the American Academy of Child and Adolescent Psychiatry, 40(9): 1086-93. 